\title{
DISTRIBUTION AND ABUNDANCE OF THE LESSER ELECTRIC RAY NARCINE BRASILIENSIS (OLFERS, 1831) (ELASMOBRANCHII: NARCINIDAE) IN SOUTHERN BRAZIL IN RELATION TO ENVIRONMENTAL FACTORS
}

\author{
Gabriel Maciel de Souza Vianna* and Carolus Maria Vooren \\ Universidade Federal de Rio Grande - Departamento de Oceanografia Biológica \\ Laboratório de Elasmobrânquios e Aves Marinhas \\ (Av. Itália, km 8 s/n, Caixa Postal 474, 96201-900 Rio Grande, RS, Brasil) \\ *gabe.vianna@gmail.com
}

\section{A B S T R A C T}

The distribution and abundance of the lesser electric ray, Narcine brasiliensis, was assessed based on bottom-trawl survey data collected off the coast of Rio Grande do Sul, southern Brazil. Between 1980 and 1984 and in 2005, 416 bottom trawl hauls were carried out at depths of 10-100 m. Narcine brasiliensis occurred mainly in waters with bottom temperature between 20 and $25^{\circ} \mathrm{C}$. Density of the species was higher between the depths of 10 and $20 \mathrm{~m}$, during the summer and autumn. The seasonal pattern of $N$. brasiliensis in the shallow coastal water of Rio Grande do Sul reflects a southward migration in summer. This is conditioned by the southward advance of warmer and high-salinity Tropical Water of the Brazil Current In winter, the return or northward migration is a response to seasonal cooling of the coastal waters and to the northward advance of cold Coastal Water of lower salinity. The latitudinal gradient in density of $N$. brasiliensis was related to the latitudinal gradient in salinity of the bottom waters. This was caused by the freshwater runoff from the Patos Lagoon establishing a physical barrier to the occurrence of the species farther south than the city of Rio Grande.

\section{RESUMO}

A distribuição e abundância da raia elétrica Narcine brasiliensis foi analisada com base em 416 lances de arrasto de fundo realizados entre as profundidades de 10- $100 \mathrm{~m}$ ao longo da costa do Rio Grande do Sul, em 1980-1984 e 2005. A espécie ocorreu prioritariamente em águas com temperatura de fundo entre 20 e $25^{\circ} \mathrm{C}$. A densidade de $N$. brasiliensis foi maior durante o verão e outono e entre as profundidades de 10 e $20 \mathrm{~m}$. O padrão sazonal de densidade da espécie nas águas costeiras rasas do Rio Grande do Sul reflete uma migração no sentido norte-sul condicionada pelo avanço das águas quentes e de alta salinidade da Água Tropical da Corrente do Brasil em direção ao sul durante o verão. A redução sazonal da temperatura da água e o avanço da Água Costeira, de baixa salinidade, determinam a migração da espécie em direção ao norte no inverno. O gradiente latitudinal de densidade de $N$. brasiliensis esteve relacionado com o gradiente latitudinal de salinidade das águas de fundo decorrente da descarga de água doce oriunda da Lagoa dos Patos, que estabelece uma barreira física para a ocorrência da espécie ao sul da cidade de Rio Grande.

Descriptors: Electric ray, Numbfish, Distribution, Abundance, Coastal waters, Seasonality.

Descritores: Raia elétrica, Treme-treme, Distribuição, Abundância, Águas costeiras, Sazonalidade.

\section{INTRODUCTION}

The distribution and abundance of marine animals is usually associated with abiotic environmental factors. Variations in salinity, temperature and/or dissolved oxygen are often the main factors that determine distribution of elasmobranchs (ECONOMAKIS; LOBEL, 1998; HOPKINS; CECH, 2003; LESSA et al., 1986; MONTGOMERY; WALKER, 2001). Seasonal changes in these variables are known to trigger events of a species' life cycle, frequently resulting in aggregations of individuals. Seasonal aggregations of elasmobranchs are often related to feeding or reproductive behavior, and have been documented for several species (RUDLOE, 1989b; COLMAN, 1997; CASTRO, 1992; VOOREN et al., 2005a; YOKOTA; LESSA 2006). The seasonal occurrence of electric rays in Florida inshore waters and shallow bays in Mexico has been associated with high water temperatures (RUDLOE 1989b; VILLAVICENCIOGARAYZAR, 1995). 
Electric rays of the genus Narcine occur in shallow waters of tropical and sub-tropical continental shelves (BIGUELOW; SCHROEDER, 1953). The genus is widely distributed in tropical latitudes, with highest diversity in the tropical West Indo-Pacific region (CARVALHO; RANDALL, 2003; CARVALHO et al., 2002). In the West Atlantic, the previously wide-ranging species $N$. brasiliensis has been subdivided into the three species: $N$. bancroftii which occurs from North Carolina to northeastern Brazil, Narcine sp. with records from Suriname to northern Brazil, and N. brasiliensis distributed from southeastern Brazil to northern Argentina (CARVALHO, 1999; McEACHRAN; CARVALHO, 2002).

Narcine brasiliensis is a small to moderate sized electric ray, attaining $45 \mathrm{~cm}$ in total length (BIGUELOW; SCHROEDER, 1953). Along the Brazilian coast $N$. brasiliensis occurs throughout the year in the shallow waters in the states of Rio de Janeiro, São Paulo, Paraná, Santa Catarina and possibly Espírito Santo (COSTA; CHAVES, 2006, ROSSI-WONGTSCHOWSKI; PAES 1993; PAIVAFILHO et al., 1987). Farther south, off Rio Grande do $\mathrm{Sul}$, the species is also known to occur in shallow coastal waters, but mostly during summer (VOOREN, 1997). However, the distribution and abundance of $N$. brasiliensis within that area and its relationship with the oceanographic factors have not been studied.

Narcine brasiliensis is not commercially important in southern Brazil, being generally discarded as part of the by-catch (VOOREN et al., 2003; MIRANDA; VOOREN, 2003). As usually happens with non-commercial species, there are no statistics on commercial fishery catches or on efforts that would enable an assessment of the population status in southern Brazil. Therefore, based on scientific survey data, this paper aims to provide information about the distribution and abundance of the lesser electric ray $N$. brasiliensis along the coast of Rio Grande do Sul, southern Brazil, and its relationship with environmental factors.

\section{Material and Methods}

The study was carried out over the inner continental shelf off southern Brazil, between Torres $\left(29^{\circ} 24^{\prime}\right.$ S) and Chuí (335'ㄱ) (Fig. 1). Due to spatial variation in oceanographic and geographical features, the study area was divided into three: a Northern Area, from Torres (29 $\left.24^{\prime} \mathrm{S}\right)$ to Solidão $\left(30^{\circ} 42^{\prime} \mathrm{S}\right)$; a Central Area, from Solidão ( $30^{\circ} 42^{\prime}$ S) to Rio Grande ( $32^{\circ} 10^{\prime}$ 'S) and a Southern Area, from Rio Grande ( $\left.32^{\circ} 10^{\prime} S\right)$ to Chuí (335's) (Fig. 1). Data was collected aboard R/V "Atlântico Sul”, a 36 m research vessel equipped with an $850 \mathrm{HP}$ central engine.

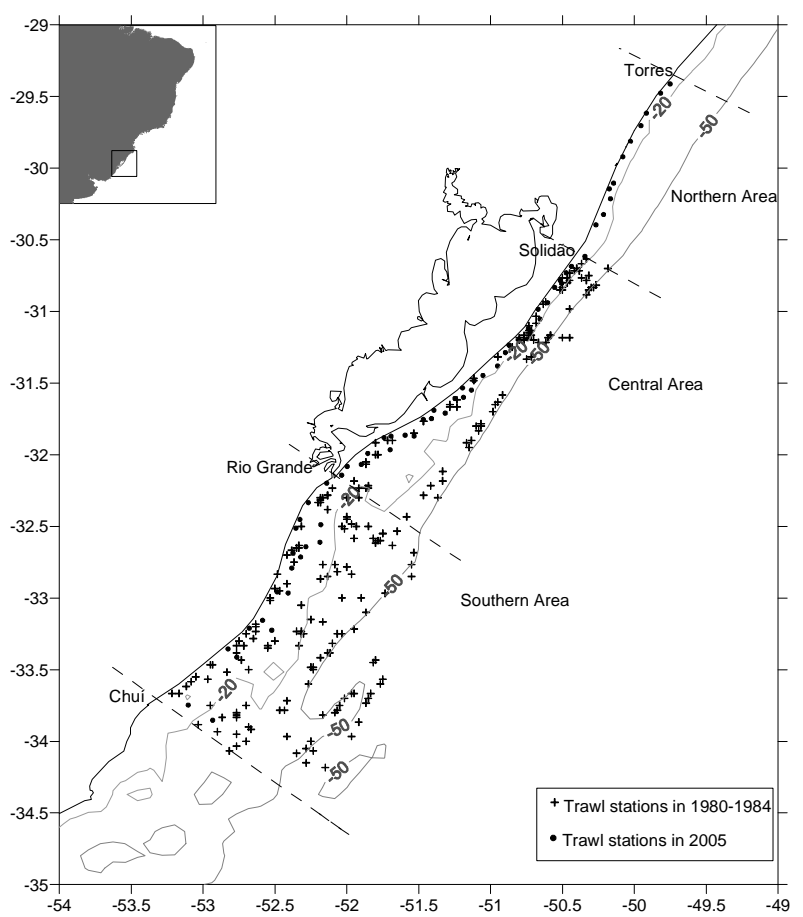

Fig. 1. Rio Grande do Sul coast (southern Brazil), with bottom trawl stations within the depths of 7 to $53 \mathrm{~m}$. 
From 1980 to 1984,10 bottom-trawl surveys were carried out in the Central and Southern Areas at depths from 10 to $100 \mathrm{~m}$. Three surveys were performed in spring (October-December), two in summer (January-March), two in autumn (April-June) and three in winter (July-September). A commercial groundfish trawl with stretched mesh of $40 \mathrm{~mm}$ in the codend and footrope length of 50 to $54 \mathrm{~m}$ was used. Trawl haul duration was 60 minutes, at the speed of $5.4 \mathrm{~km} \mathrm{~h}-1$. Trawl stations were located along transect lines perpendicular to the coast. Bottom temperature was measured at the end of each trawl haul, using a reversing thermometer or a bathythermograph.

During the summer of 2005, a trawl survey was carried out between depths of 7 and $20 \mathrm{~m}$ throughout the study area (Northern, Central and Southern Areas). A shrimp trawl with a $20.5 \mathrm{~m}$ long footrope and stretched mesh of $50 \mathrm{~mm}$ was used. The footrope was rigged with a chain of $1.3 \mathrm{~kg} \mathrm{~m}-1$. Trawl haul duration was 30 minutes at the speed of $5.5 \mathrm{~km} \mathrm{~h}$ 1. At the end of each tow, bottom temperature and salinity were measured using a CTD device (Idronaut Oceanseven 316). The study area was divided into 15 strata by equidistant lines perpendicular to the coast. A total of 62 trawl stations were randomly positioned according to the surface area of each stratum. Since captures of $N$. brasiliensis occurred only between 10 and $53 \mathrm{~m}$ depths, the study of the spatial distribution of the species was based on the 286 tows made between these depths during the 11 surveys.

Due to differences in footrope lengths among surveys, fishing efforts were standardized to a mouth opening of $51 \mathrm{~m}$, the most frequent value in the surveys. The catch per unit of effort (CPUE) in kg per hour of trawling was used as the index of density of $N$. brasiliensis. The relative frequency of occurrence (FO $\%$ ) was expressed as the number of trawl stations with the species present, as a percentage of the total number of stations. Mean of CPUE refers to the data of the trawl stations at which $N$. brasiliensis was caught, and differences between these means were tested by the Mann-Whitney test (STATSOFT, 1995). To analyze differences between absolute frequencies of occurrence Fisher's Exact test (STATSOFT, 1995) and the Chi-Square test (ZAR, 1984) were employed. All tests were carried out at a significance level of 0.05 .

\section{Results}

Spatial and Temporal Variation in Density and Frequency of Occurrence

The general pattern of mean CPUE was of a latitudinal gradient in density of $N$. brasiliensis, with the highest density in the Northern Area (24.66 $\mathrm{kg} \mathrm{h}-1)$, intermediate values (0.10-2.40 $\mathrm{kg} \mathrm{h}-1)$ in the
Central Area, and the lowest densities in the Southern Area (0.01-0.04 kg h-1) (Table 1). The species was also more widely distributed in the Northern and Central Areas, where the frequencies of occurrence were $38 \%$ and $6-63 \%$, respectively. In the Southern Area, N. brasiliensis was absent or occurred at a frequency of $6-8 \%$ (Table 1). In the summer of 2005 , the CPUE of the Northern Area was significantly different from that of the Central Area $(U=3, p=0.03)$, but there was no significant difference in frequency of occurrence between these areas (Fisher's exact test, $p=$ $0.73)$.

In the Central Area, the summer-autumn and winter-spring periods presented significant differences in density and in frequency of occurrence of $N$. brasiliensis $\left(\mathrm{U}=29.5, \mathrm{p}=0.02 ; \chi^{2}=7.02, \mathrm{p}<0.05\right)$, with maximum values during autumn $(2.40 \mathrm{~kg} \mathrm{~h}-1$ and $44 \%)$, and minimum values in winter $(0.10 \mathrm{~kg} \mathrm{~h}-1$ and 11\%). In the Southern Area, density and frequency of occurrence was also higher in summer-autumn and lower in winter. No rays were caught in spring (Table 1). A similar pattern of variation occurred in the number of animals captured per hour of trawling (Table 1).

Bathymetric distribution of $N$. brasiliensis ranged from 10 to $53 \mathrm{~m}$ depth. Only in winter was the species caught at depths greater than $40 \mathrm{~m}$, with no significant difference in the frequency of occurrence between depths of 10-20 and 41-53 m (Fisher's exact test, $\mathrm{p}=1.00$ ) (Table 2). In 10-20 m depth in the Central Area, N. brasiliensis occurred during all seasons, but density and frequency of occurrence in summer and autumn combined were respectively 8.8 and 2.5 times greater than those in winter and spring combined, with significant differences between the values $\left(\mathrm{U}=12, \mathrm{p}=0.01 ; \chi^{2}=\right.$ $3.96, \mathrm{p}<0.05)$ (Table 2). Thus, at these depths of the Central Area, the species was approximately 20 times more abundant in summer-autumn than in the winterspring period.

\section{Relationship between Distribution and Oceanographic Variables}

Narcine brasiliensis was caught at bottom temperatures between 16.0 and $25.0^{\circ} \mathrm{C}$ (Fig. 2). At temperatures between 20.0 and $25.0^{\circ} \mathrm{C}$, density and frequency of occurrence were $3.5 \mathrm{~kg} \mathrm{~h}-1$ and $23 \%$, respectively. These values were significantly higher than those at bottom temperatures of 16.0 to $19.9^{\circ} \mathrm{C}$ $\left(0.2 \mathrm{~kg} \mathrm{~h}-1\right.$ and $11 \% ; \mathrm{U}=70, \mathrm{p}=0.05 ; \chi^{2}=10.3$, p< 0.05) (Fig. 2). In the Central and Southern Areas, higher densities of $N$. brasiliensis were registered in summer-autumn of 1980-1984 when bottom temperatures were higher than $20.0^{\circ} \mathrm{C}$ in the coastal waters (Tables 2 and 3 ). 
Table 1. Number of trawl hauls $(\mathrm{N})$, mean $\operatorname{CPUE}(\mathrm{kg} / \mathrm{h})$ and mean $\mathrm{CPUE}_{(\mathrm{n})}$ (individuals $/ \mathrm{h}$ ) standardized to groundhope length of $51 \mathrm{~m}$ and relative frequency of occurrence (FO\%) of Narcine brasiliensis off Rio Grande do Sul, southern Brazil, in depths of 10-53 m during 11 surveys in 1980-1984, and of 10-20 m in one survey in 2005.

\begin{tabular}{|c|c|c|c|c|c|c|c|c|c|c|c|c|c|}
\hline \multirow{2}{*}{ Season } & \multirow{2}{*}{ Survey } & \multicolumn{4}{|c|}{ Northern Area } & \multicolumn{4}{|c|}{ Central Area } & \multicolumn{4}{|c|}{ Southern Area } \\
\hline & & $\mathrm{N}$ & CPUE & $\mathrm{CPUE}_{(\mathrm{n})}$ & $\mathrm{FO} \%$ & $\mathrm{~N}$ & CPUE & $\mathrm{CPUE}_{(\mathrm{n})}$ & $\mathrm{FO} \%$ & $\mathrm{~N}$ & CPUE & $\mathrm{CPUE}_{(\mathrm{n})}$ & FO\% \\
\hline \multirow{4}{*}{ Spring } & 1980 & 0 & - & - & - & 5 & 1.40 & 0.80 & 20 & 5 & 0 & 0 & 0 \\
\hline & 1983 & 0 & - & - & - & 18 & 0.12 & 0.17 & 11 & 6 & 0 & 0 & 0 \\
\hline & 1984 & 0 & - & - & - & 4 & 0.10 & 0.25 & 25 & 14 & 0 & 0 & 0 \\
\hline & Total & $\mathbf{0}$ & - & - & - & 27 & 0.35 & 0.30 & 15 & 25 & $\mathbf{0}$ & $\mathbf{0}$ & 0 \\
\hline \multirow{4}{*}{ Summer } & 1981 & 0 & - & - & - & 2 & 3.50 & 8.50 & 50 & 15 & 0.03 & 0.06 & 7 \\
\hline & 1982 & 0 & - & - & - & 8 & 2.20 & 6.00 & 63 & 17 & 0.02 & 0.06 & 6 \\
\hline & 2005 & 13 & 24.66 & 71.4 & 38 & 30 & 1.26 & 3.24 & 20 & 15 & 0 & 0 & 0 \\
\hline & Total & 13 & 24.66 & 71.4 & 38 & 40 & 1.60 & 4.05 & 30 & 47 & 0.02 & 0.04 & 4 \\
\hline \multirow{3}{*}{ Autumn } & 1981 & 0 & - & - & - & 10 & 0.60 & - & 30 & 16 & 0.01 & 0.06 & 6 \\
\hline & 1983 & 0 & - & - & - & 8 & 4.40 & 7.50 & 62 & 17 & 0.04 & 0.06 & 6 \\
\hline & Total & 0 & - & - & - & 18 & 2.40 & 7.50 & 44 & 33 & 0.02 & 0.06 & 6 \\
\hline \multirow{4}{*}{ Winter } & 1980 & 0 & - & - & - & 10 & 0.10 & 0.30 & 20 & 17 & 0 & 0 & 0 \\
\hline & 1981 & 0 & - & - & - & 13 & 0.10 & 0.07 & 8 & 13 & 0.03 & 0.07 & 8 \\
\hline & 1983 & 0 & - & - & - & 16 & 0.10 & 0.06 & 6 & 14 & 0 & 0 & 0 \\
\hline & Total & 0 & - & - & - & 39 & 0.10 & 0.12 & 11 & 44 & 0.01 & 0.02 & 2 \\
\hline
\end{tabular}

Table 2. Number of trawl hauls $(\mathrm{N})$, mean CPUE $(\mathrm{kg} / \mathrm{h})$ and mean $\mathrm{CPUE}_{(\mathrm{n})}$ (individuals/h) standardized to groundrope of $51 \mathrm{~m}$ and frequency of occurrence (FO\%) of Narcine brasiliensis in different depths strata in the Central Area. Data collected in surveys from 1980 to 1984 and in 2005, off Rio Grande do Sul (Southern Brazil).

\begin{tabular}{|c|c|c|c|c|c|c|c|c|c|c|c|c|c|c|c|c|c|c|c|c|}
\hline \multirow{2}{*}{$\begin{array}{l}\text { Depth } \\
\text { (m) }\end{array}$} & \multicolumn{4}{|c|}{ Spring } & \multicolumn{4}{|c|}{ Summer } & \multicolumn{4}{|c|}{ Autumn } & \multicolumn{4}{|c|}{ Winter } & \multicolumn{4}{|c|}{ Total } \\
\hline & $\mathrm{N}$ & CPUE & $\begin{array}{l}\text { CPUE } \\
\text { (n) }\end{array}$ & $\begin{array}{l}\text { FO } \\
\% \\
\end{array}$ & $\mathrm{~N}$ & CPUE & $\begin{array}{l}\text { CPUE } \\
\text { (n) }\end{array}$ & $\begin{array}{l}\text { FO } \\
\%\end{array}$ & $\mathrm{~N}$ & CPUE & $\begin{array}{c}\text { CPUE } \\
\text { (n) }\end{array}$ & $\begin{array}{l}\text { FO } \\
\% \\
\end{array}$ & $\mathrm{~N}$ & CPUE & $\begin{array}{l}\text { CPUE } \\
\text { (n) }\end{array}$ & $\begin{array}{l}\text { FO } \\
\%\end{array}$ & $\mathrm{~N}$ & CPUE & $\begin{array}{c}\text { CPUE } \\
\text { (n) }\end{array}$ & $\begin{array}{l}\text { FO } \\
\%\end{array}$ \\
\hline $10-20$ & 18 & 0.51 & 0.61 & 22 & 37 & 1.69 & 2.06 & 32 & 8 & 4.61 & 8.71 & 75 & 19 & 0.10 & 0.14 & 10 & 82 & 1.35 & 1.95 & 29 \\
\hline $21-30$ & 1 & 0 & 0 & 0 & 0 & - & - & - & 2 & 0.18 & 0.50 & 50 & 4 & 0 & 0 & 0 & 7 & 0.05 & 0.01 & 14 \\
\hline $31-40$ & 2 & 0 & 0 & 0 & 0 & - & - & - & 3 & 0.50 & 1.00 & 33 & 2 & 0 & 0 & 0 & 7 & 0.22 & 0.04 & 14 \\
\hline $41-50$ & 6 & 0 & 0 & 0 & 3 & 0 & 0 & 0 & 4 & 0 & 0 & 0 & 12 & 0.07 & - & 8 & 25 & 0.03 & 0.00 & 4 \\
\hline $51-53$ & 0 & - & - & - & 0 & - & - & - & 1 & 0 & 0 & 0 & 2 & 0.78 & 0.80 & 50 & 3 & 0.52 & 0.02 & 33 \\
\hline
\end{tabular}

In summer 2005, mean and range of bottom temperature were $21.1^{\circ} \mathrm{C}\left(20.4-22.9^{\circ} \mathrm{C}\right)$ in the Northern Area, $22.9^{\circ} \mathrm{C}\left(19.6-25.2^{\circ} \mathrm{C}\right)$ in the Central Area, and $23.6^{\circ} \mathrm{C}\left(22.9-24.1^{\circ} \mathrm{C}\right)$ in the Southern Area. The observations also showed a south-north gradient in salinity with means and ranges of 34.1 UPS (33.6-35.0 UPS) in the Southern Area, 35.7 UPS (34.4-36.3 UPS) in the Central Area, and 36.2 UPS (36.1-36.3 UPS) in the Northern Area. At the same time, there was also a south-north gradient in density of $N$. brasiliensis, with the lowest density in the Southern Area, intermediate density in the Central Area, and the highest density in the Northern Area (Table 1), with the highest density clearly associated with the high salinity that dominated in the Northern Area (Fig. 3). 


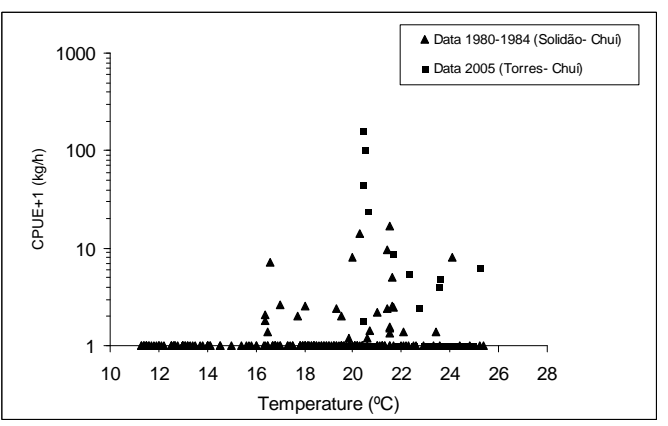

Fig. 2. Relationship between CPUE of Narcine brasiliensis and bottom temperature at trawl stations off Rio Grande do Sul (southern Brazil) during surveys from 1980 to 1984 and in 2005. CPUE standardized to groundrope of $51 \mathrm{~m}$.

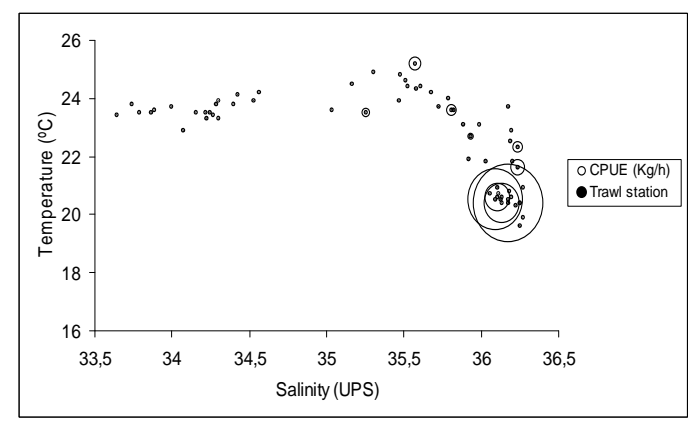

Fig. 3. Relationship between temperature, salinity and magnitude of CPUE of Narcine brasiliensis in trawl stations at depths of 10 to $20 \mathrm{~m}$ in February 2005 along the coast of Rio Grande do Sul. The diameter of the circles is proportional to CPUE in $\mathrm{kg} / \mathrm{h}$.

Table 3. Bottom temperature $\left({ }^{\circ} \mathrm{C}\right)$ in each depth strata in depths from 10 to $53 \mathrm{~m}$ during surveys from 1980 to 1984 and in 2005 in the Central and Southern Area off Rio Grande do Sul (southern Brazil). N= number of trawl hauls; $(-)=$ no data.

\begin{tabular}{|c|c|c|c|c|c|c|c|c|c|c|c|c|}
\hline \multirow{2}{*}{$\begin{array}{l}\text { Depth } \\
\text { (m) }\end{array}$} & \multicolumn{3}{|c|}{ Spring } & \multicolumn{3}{|c|}{ Summer } & \multicolumn{3}{|c|}{ Autumn } & \multicolumn{3}{|c|}{ Winter } \\
\hline & $\mathrm{N}$ & Mean & Range & $\mathrm{N}$ & Mean & Range & $\mathrm{N}$ & Mean & Range & $\mathrm{N}$ & Mean & Range \\
\hline \multicolumn{13}{|c|}{ Central Area } \\
\hline $10-20$ & 12 & 18.9 & $17.7-20.0$ & 37 & 22.6 & $19.3-25.2$ & 7 & 21.3 & $21.0-21.6$ & 13 & 15.8 & $13.0-18.0$ \\
\hline $31-40$ & 2 & 17.6 & $16.7-18.4$ & 0 & - & - & 3 & 21.0 & $20.1-21.7$ & 2 & 17.0 & $16.7-17.3$ \\
\hline $41-50$ & 4 & 17.3 & $16.8-17.8$ & 3 & 18.3 & $18.0-18.7$ & 4 & 21.1 & $20.4-21.5$ & 11 & 16.3 & $11.5-18.4$ \\
\hline $51-53$ & 0 & - & - & 0 & - & - & 1 & 21.0 & - & 2 & 18.2 & $18.0-18.4$ \\
\hline $31-40$ & 2 & 18.2 & $17.9-18.5$ & 2 & 15.6 & $14.1-17.0$ & 3 & 20.4 & $19.8-21.2$ & 1 & 13.5 & - \\
\hline $41-50$ & 3 & 13.3 & $12.0-15.4$ & 4 & 15.6 & $13.2-18.0$ & 7 & 19.8 & $19.2-20.3$ & 7 & 12.0 & $11.3-14.5$ \\
\hline $51-53$ & 2 & 12.4 & $12.1-12.6$ & 5 & 17.1 & $13.7-20.4$ & 3 & 19.4 & $19.3-19.5$ & 4 & 12.7 & $11.3-16.8$ \\
\hline
\end{tabular}

\section{Discussion}

In southern Brazil, seasonal variations of the thermohaline proprieties of the shelf water are mainly determined by the freshwater runoff from the Patos Lagoon and by the seasonal influences of the Brazil Current and the coastal branch of the Malvinas Current (GARCIA, 1997). In summer 2005, the waters from 10 to $20 \mathrm{~m}$ depth along the coast of Rio Grande do Sul could be divided into three well defined areas, in terms of thermohaline properties. The Northern Area was under the influence of Tropical Water, characterized by water temperatures and salinity above $20^{\circ} \mathrm{C}$ and 36 UPS, respectively. The Southern Area was dominated by Coastal Waters with high temperatures $\left(23-24^{\circ} \mathrm{C}\right)$ and low salinity (33.6-34.4 UPS). The Central Area was characterized by the mixing of Tropical Water and Coastal Water, being considered a transitional area with a temperature of $19-25.2^{\circ} \mathrm{C}$ and salinity of 34.5 36.5 UPS (Fig. 3) (Weigert et al., 2005). 
Density of $N$. brasiliensis was higher in bottom temperatures greater than $20^{\circ} \mathrm{C}$, which was consistent with observations of the sluggish behavior of lesser electric rays in water temperatures below $20^{\circ} \mathrm{C}$ (Rudloe, 1989a). In summer 2005, the temperatures throughout the study area were mostly higher than $20^{\circ} \mathrm{C}$ and, therefore, within the preferred temperature range. However, the density of the species was much lower in the Southern and Central Areas than in the Northern Area. This latitudinal gradient was clearly associated with the predominance of the more saline Tropical Water (36.0-36.3 UPS) in the Northern Area, and of the less saline Coastal Water (33.6-36.0 UPS) farther south. Weigert et al. (2005) showed that the isohaline of 34.5 UPS occurred south of the mouth of the Patos Lagoon, which therefore constitutes a natural barrier to the distribution of $N$. brasiliensis in the southwestern Atlantic. The less saline Coastal Water further south from the Patos Lagoon mouth results from the combined influence of continental discharge through the Patos Lagoon and of the outflow of the Rio de la Plata (Odebrecht \& Castello, 2001). This relationship between salinity and distribution patterns has been described for some coastal elasmobranchs (Hopkins and Cech, 2003). The sporadic occurrence of $N$. brasiliensis south of $32^{\circ} \mathrm{S}$ is not satisfactorily explained solely by temperature variations within the area (MENNI; STEHMANN 2000). Thus, the sporadic occurrence of $N$. brasiliensis to the south of the Patos Lagoon and also off Uruguay and northern Argentina may be explained by the low salinity of the Coastal Waters.

The present results confirm that $N$. brasiliensis occurs on the shelf of Rio Grande do Sul as a summer migrant, as also stated by Vooren (1997). In summer, the species is abundant and widespread in coastal waters at depths down to $20 \mathrm{~m}$. In winter, the species continues to be present, though in low density and mostly at depths of 40-50 m.

On the shelf between Solidão and Chuí, the bottom temperature varied seasonally in 1981-1983 as follows: in the shallow coastal waters, it was shown to be mostly $12-17^{\circ} \mathrm{C}$ in winter and $20-22^{\circ} \mathrm{C}$ in summer and autumn; at depths of $40-100 \mathrm{~m}, 15-18^{\circ} \mathrm{C}$ in summer, winter and spring; and $18-20^{\circ} \mathrm{C}$ in autumn (HAIMOVICI et al., 1996). The seasonal pattern of the shallow coastal waters reflects two processes: First, heating in summer and cooling in winter of the entire water column, due to the seasonal variation of insolation and air temperature, which ranges between the means of $13^{\circ} \mathrm{C}$ in July and $24^{\circ} \mathrm{C}$ in January (KLEIN, 1997); Secondly, the distribution of the Tropical Water over the shelf caused by the southward flowing Brazil Current in summer, combined with the northward flowing water mass in winter. This consists of Coastal Water formed by the mixing of Subantarctic Water of the Falkland current and of the freshwater run off of the Rio de la Plata and the Patos Lagoon (GARCIA, 1997; NIENCHESKI; FILLMANN, 1997; ODEBRECHT; CASTELLO, 2001). Thus, the seasonal pattern of $N$. brasiliensis in the shallow coastal water of Rio Grande do Sul reflects a southward migration in summer conditioned by the southward advance of the warmer and high-salinity Tropical Water of the Brazil Current. This is followed by the return northward migration in winter as a response to the seasonal cooling of the coastal waters and to the northward advance of cold Coastal Water of low salinity. The predominance of bottom temperatures of $15-18^{\circ} \mathrm{C}$ during most of the year at depths of 40-100 m is evidence that South Atlantic Central Water, formed at the Subtropical Convergence with a temperature of $10-20^{\circ} \mathrm{C}$ and salinity of 35.0 36.0 UPS (GARCIA, 1997), predominates at those depths with little seasonal variation. In winter, these deeper waters are warmer than the shallow coastal waters, which may explain why in this period $N$. brasiliensis occurs mostly at depths of 40-50 m.

In Florida, electric rays of the genus Narcine occurred patchily, at high densities in small and sharply defined areas, and once identified, such areas consistently yielded higher catches than those of adjacent sites (RUDLOE, 1989b). These areas of high densities were also observed for $N$. brasiliensis in the present study. In the survey of summer $2005,75 \%$ of all individuals sampled were caught at just two trawl stations. This observation suggests that $N$. brasiliensis may also aggregate at specific sites on the coast of southern Brazil. The species feeds basically on invertebrates buried in the sea bottom, and in southern Brazil polychaetes are an important item of its diet (BIGELOW; SCHROEDER, 1953; BORNATOWSKI et al., 2006). The higher density of $N$. brasiliensis at specific sites could be related to the occurrence of patches of high densities of the buried prey items. Studies on the feeding ecology and reproductive biology of the species in the area could bring insightful information about the aggregating behavior of the species.

The fishery industry is the main threat to elasmobranchs in southern Brazil and has been responsible for the decline of several elasmobranch populations in this area over the past 30 years (MIRANDA; VOOREN, 2003; VOOREN; KLIPPEL, 2005b). Narcine brasiliensis is a by-catch product of the bottom trawl fisheries of southern Brazil and is usually discarded after being caught (MIRANDA; VOOREN, 2003). It is highly probable, therefore, that the population of this area has been severely impacted by these fisheries, since the survival of rays discarded by bottom trawl fisheries is usually low (LAPTIKHOVSKY, 2004). Considering the vulnerability of the species to bottom trawl fisheries, it is reasonable to affirm that the impact of trawling on 
$N$. brasiliensis populations may not be an event exclusive to southern Brazil, and creates great concern regarding the conservation of this species throughout its entire geographical range.

\section{ACKNOWLEDGEMENTS}

The authors' thanks are due to Dr. Manoel Haimovici, Dr. Marlise Benvenuti, Dr. Monica Brick Peres for their perspicacious suggestions, to Dr. Paul Gerard Kinas for the statistical support, to CAPES for their financial support, and to Drs. Marcelo Carvalho, Anne Rudloe and Villavicencio-Garayzar for the references provided.

\section{REFERENCES}

BIGELOW, H. B.; SCHROEDER, W. C. Fishes of the Western North Atlantic. Part Two: Sawfishes, Guitarfishes, Skates and Rays. New Haven: Memoir Sears Foundation for Marine Research, 1953. n. 1, 588 p.

BORNATOWSKI, H.; ABILHOA, V.; FREITAS, M. O. Feeding of Narcine brasiliensis at Ubatuba-Enseada bay, São Francisco do Sul, Santa Catarina, Brazil. Estud. Biol., v. 28, n. 62, p. 57-60, 2006

CARVALHO, M. R. de. A systematic revision of the electric ray genus Narcine Henle, 1984 (Chondrichthyes: Torpediniforme: Narcinidae) and the higher level phylogenetic relationship of the orders of elasmobranch fishes (Chondrichthyes). Tese (Doutorado), City University of New York, USA, 1999. $726 \mathrm{p}$.

CARVALHO, M. R. de; SÉRET, B.; COMPAGNO, L. J. V. A new species of electric ray of the genus Narcine Henle, 1834 from the south-western Indian Ocean (Chondrichthyes: Torpediniformes: Narcinidae). S. Afr J. mar. Sci., v. 24, p. 135-149, 2002.

CARVALHO, M. R. de; RANDALL, J. E. Numbfishes from the Arabian Sea and surrounding gulfs, with description of a new species from Oman (Chondrichthyes: Torpediniformes: Narcinidae) Ichthyol. Res., v. 50, p. 59-66, 2003.

CASTRO, J. The shark nursery of Bull Bay, South Carolina, with a review of the shark nurseries of the southeastern coast of the United States. Environ. Biol. Fishes, v. 38 , p. 37-38, 1993.

COLMAN, J. G. A review of the biology and ecology of the whale shark. J. Fish Biol., v. 51, p. 1219-1234, 1997.

COSTA, L; CHAVES, P. T. C. Elasmobrânquios capturados pela pesca artesanal na costa sul do Paraná e norte de Santa Catarina, Brasil. Biota Neotrop., v. 6, n. 3bn0270603, 2006.

ECONOMAKIS, A. E.; LOBEL, P. S. Aggregation behavior of the grey reef shark, Carcharhinus amblyrhychos at Johnston Atoll, Central Pacific Ocean. Environ. Biol. Fishes v. 51, p. 129-139, 1998.
GARCIA, C. A. E. Physical Oceanography. In: U. SEELIGER,U.; C. ODEBRECHT, C.; CASTELLO, J. P. (Ed.). Subtropical convergence environments. The coast and sea in the Southwestern Atlantic. Berlin: Springer Verlag, 1997. p. 94-95.

HAIMOVICI, M.; MARTINS, A. S.; VIEIRA, P. C. Distribuição e abundância de peixes teleósteos demersais sobre a plataforma continental do sul do Brasil. Rev. Bras. Biol. v. 56, n. 1, p. 27-50, 1996.

HOPKINS, T. E.; CECH, J. J. The influence of environmental variables on the distribution and abundance of three elasmobranchs in Tomales Bay, California. Environ. Biol. Fishes, v. 66, p. 279-291, 2003.

KLEIN, A. H. F. Regional Climate: In: SEELIGER, U.; ODEBRECHT, C.; CASTELlO, J. P. (Ed.). Subtropical convergence environments: The coast and sea in the Southwestern Atlantic. Berlin: Springer Verlag, 1997. p. 5.

LAPTIKHOVSKY, V. V. Survival rates for rays discarded by the bottom trawl squid fishery off the Falkland Islands. Fish. Bull., v. 102, p. 757-759, 2004.

LESSA, R.; VOOREN, C. M.; LAHAYE, J. Desenvolvimento e ciclo sexual das fêmeas, migrações e fecundidade da viola Rhinobatos horkelii (Muller \& Henle, 1841) do sul do Brasil. Atlântica, v. 8, p. 5-34, 1986.

McEACHRAN, J. D.; CARVALHO, M. R. de . Batoid fishes. In: Carpenter, K. E.; NIEM V. H (Ed.). FAO species identification guide for fishery purposes. The living marine resources of the Western Central Atlantic, v. 1. Rome, 2002.

MENNI, R. C.; STEHMANN, M. F. W. Distribution, environment and biology of batoid fishes off Argentina, Uruguay and Brazil. A review. Revta Mus. Argentino Cienc. nat., n.s., v. 2, n. 1, p. 69-109, 2000.

MIRANDA, L. V. de; VOOREN, C. M. Captura e esforço de pesca de elasmobrânquios demersais no sul do Brasil nos anos de 1975 a 1997. Frente Marítimo, v. 19(B), p. 217-231, 2003.

MONTGOMERY, J. C.; WALKER, M. M. Orientation and navigation in elasmobranchs: which way forward?. Environ. Biol. Fishes, v. 60, p. 109-116, 2001.

NIENCHESKI, L. F; FILLMANN, G. Chemical Characteristics. p: 96-97. In: SEELIGER, U.; ODEBRECHT, C.; CASTELlO, J. P. (Ed.). Subtropical Convergence Environments: The coast and sea in the Southwestern Atlantic. Berlin: Springer Verlag, 1997. p. 96-97.

PAIVA-FILHO, A. M; GIANNINI, R; F.; RIBEIRO-NETO, F. B.; SCHMIEGELOW, J. M. M. Ictiofauna do complexo baia-estuário de Santos, São Vicente, SP, Brasil. Relat. técn. Inst. oceanogr. , v. 17, p. 1-10, 1987.

ODEBRECHT, C.; CASTELlO, J. P. The convergence ecosystem in Southwest Atlantic. Costa marine ecosystems of Latin America, v. 144, p. 147-165, 2001.

ROSSI-WONGTSCHOWSKI, C. L. D. B.; PAES, E. T. Padrões espaciais e temporais da comunidade de peixes demersais do litoral norte do estado de São PauloUbatuba, Brasil. Publção esp. Inst. oceanogr., v. 10, 169-188, 1993 
RUDLOE, A. Captive maintenance of the lesser electric ray, with observations of feeding behavior. Progressive FishCulturist, v. 51, p. 37-41, 1989a.

RUDLOE, A. Habitat preferences, movement, and reproductive seasonality of the lesser electric ray, Narcine brasiliensis. Northeast Gulf Science v. 10, n. 2, p. 103-112, 1989b.

STATSOFT. Statistics for Windows. Tulsa, USA, 1995.

VILLAVICENCIO-GARAYZAR, C. Distribución temporal y condición reproductiva de las rayas (Pises: Batoideo) capturadas comercialmente en Bahía Almejas, B.C.S., México. Revta Invest. Cient. Ser. Cienc. Mar. UABCS, v. 6, n. 1-2, p. 1-12, 1995.

VOOREN, C. M. Demersal Elasmobranchs. p: 141-145 In: SEELIGER, U. ; ODEBRECHT, C.; CASTELLO, J. P. (Ed.). Subtropical Convergence Environments: The coast and sea in the Southwestern Atlantic. Berlin: Springer Verlag, 1997.

VOOREN, C. M.; NAVES L. C.; ROMAY, A. F. L. Guia para a identificação de tubarões e raias em desembarques da pesca no Rio Grande do Sul. Documentos técn. Oceanografia, Fund. Univ. Rio Grande, v. 12, p. 54, 2003.

VOOREN, C. M. ; LESSA, R. P. ; KLIPPEL, S. Biologia e status de conservação da viola Rhinobatos horkelii. In: VOOREN, C. M.; KLIPPEL, S. (Ed.). Ações para a conservação de tubarões e raias no sul do Brasil. Porto Alegre: Igaré, 2005a. p. 33-56.
VOOREN, C. M.; KLIPPEL, S.; GALINA, A. B. Os elasmobrânquios das águas costeiras da Plataforma Sul. In: VOOREN, C. M.; S. KLIPPEL, S. (Ed. ). Ações para a conservação de tubarões e raias no sul do Brasil. Porto Alegre: Igaré, 2005b. p. 113-120.

WEIGERT, S. C.; KLIPPEL, S.; MADUREIRA, L. S. P.; VOOREN, C. M. 2005. As águas costeiras da Plataforma Sul como ambiente físico. In: VOOREN, C. M.; KLIPPEL, S. (Ed.). Ações para a conservação de tubarões e raias no sul do Brasil. Porto Alegre: Igaré, 2005. p. 23-32.

YOKOTA, L.; LESSA, R. P. A nursery area for sharks and rays in Northeastern Brazil. Environ. Biol.Fishes, v. 75, p. 349-360, 2006.

ZAR, J. H. Biostatistical analysis. Englewood Cliffs, N.J.: Prentice-Hall, 1984. 718 p.

(Manuscript received 12 August 2008; revised 15 December 2008; accepted 20 January 2009) 